\title{
SIKAP ORANG TUA TENTANG PENDIDIKAN SEKS PADA REMAJA DI DESA JATILENGGER RT 04/ RW 02 KECAMATAN PONGGOK KABUPATEN BLITAR
}

\author{
Nining Istighosah ${ }^{1}$, Yunita Dwi Wulansari ${ }^{2}$ \\ ${ }^{1,2}$ Akademi Kebidanan Dharma Husada Kediri Jawa Timur
}

\begin{abstract}
Abstrak
Di Indonesia hingga kini pendidikan seks terus ditolak banyak pihak. Pendidikan sekss dicurigai sebagai kegiatan kontra produktif dan mengarah pada pornografi. Akses terhadap pendidikan seks juga minim, serta hanya sebagian orang tua bersikap positif terhadap pendidikan seks yang diberikan kepada remaja. Banyak orang tua yang bersikap canggung untuk terbuka dengan anak-anak tentang persoalan seksualitas. Padahal, dengan sikap keliru tersebut, anak justru akan berusaha mencari sendiri pengetahuan yang berhubungan dengan kehidupan seksual. Akibatnya pengetahuan yang diperoleh bisa setengah-setengah atau bahkan keliru sehingga dapat menjerumuskan anak pada hal yang negatif. Penelitian ini menggunakan metode deskriptif. Sampel pada penelitian ini adalah seluruh orang tua di Desa Jatilengger RT 04/ RW 02 Kecamatan Ponggok Kabupaten Blitar sebanyak 30 responden.

Hasil penelitian ini didapatkan bahwasanya sikap orang tua tentang pendidikan seks pada remaja adalah positif sebanyak 14 responden (46,66\%). Dari berbagai komponen sikap didapatkan bahwasanya sikap orang tua tentang pendidikan seks pada remaja adalah negatif 16 sebanyak responden $(53,33 \%)$.

Simpulan dari penelitian ini adalah pentingnya pemberian informasi pada orang tua khususnya yang mempunyai anak pada usia remaja tentang pentingnya pendidikan seks pada remaja dengan menggunakan pendekatan sesuai dengan tahapan perkembangan remaja.
\end{abstract}

Kata kunci : Sikap Orang Tua, Pendidikan Seks, Remaja

Korespondensi: Ds. Pesantren RT 009/RW 002 Kediri Jawa Timur HP: 081231352032 ,email: dealovanining@gmail.com 


\section{Pendahuluan}

Saat anak memasuki usia remaja tugas dan tanggung jawab orang tua untuk mendidik anaknya semakin besar, karena remaja adalah seorang yang sedang tumbuh menuju proses pematangan yaitu peralihan dari masa kanak-kanak menuju dewasa. Namun pada tahap ini emosinya belum dapat mengikuti perkembangan fisiknya sehingga sering menimbulkan gejolak maka pada masa ini perlu mendapat perhatian. Salah satunya adalah pendidikan tentang seks agar anak berperilaku sehat baik secara fisik, mental maupun reproduksinya.

Di Indonesia hingga kini pendidikan seks terus ditolak banyak pihak. Pendidikan sekss dicurigai sebagai kegiatan kontra produktif dan mengarah pada pornografi. Akses terhadap pendidikan seks juga minim, serta hanya sebagian orang tua bersikap positif terhadap pendidikan seks yang diberikan kepada remaja. Banyak orang tua yang bersikap canggung untuk terbuka dengan anak-anak tentang persoalan seksualitas. Padahal, dengan sikap keliru tersebut, anak justru akan berusaha mencari sendiri pengetahuan yang berhubungan dengan kehidupan seksual. Akibatnya pengetahuan yang diperoleh bisa setengah-setengah atau bahkan keliru sehingga dapat menjerumuskan anak pada hal yang negatif.

Di dunia khususnya di negara maju seperti Amerika sebanyak 9\% remaja pernah melahirkan bayi dengan 62 kelahiran per 1000 perempuan,sedang di Indonesia sendiri sebanyak 100 kelahiran per 1000 perempuan. (Menurut survei Demografi dan Kesehatan Indonesia, 2010).

Menurut data Kementrian Kesehatan Indonesia 2012, 39\% remaja mempunyai teman yang sudah pernah melakukan hubungan seks pranikah dan $6,9 \%$ responden pernah melakukan hubungan seks pranikah. Menurut survey Komnas Perlindungan Anak 2012 , 93,7\% remaja pernah ciuman dan oral seks, $62,7 \%$ remaja SMP tidak perawan,21,2\% remaja SMU pernah aborsi dan $97 \%$ pernah nonton film porno.
Di Jawa Timur pada tahun 2006 sekitar $26 \%$ remaja mengalami hamil di luar nikah. Sedangkan pada tahun 2010 menjadi 37\% mengalami hamil pra nikah. Angka ini meningkat $11 \%$ dari tahun 2006 . (Notoatmodjo,2011)

Kasus seks pra nikah yang melibatkan remaja atau anak dibawah umur makin meningkat. Sejak bulan Januari hingga Maret 2011, setidaknya terjadi 25 kasus pencabulan serta persetubuhan dan beredar 3 video seks yang diperankan oleh remaja di Kabupaten Blitar. (Data Unit Perlindungan Perempuan dan Anak Polres Blitar 2011).

Berdasarkan uraian di atas, tujuan dalam penelitian ini adalah untuk mengetahui Bagaimana sikap orang tua tentang pendidikan seks pada remaja di Desa Jatilengger RT 04/ RW 02 Kecamatan Ponggok Kabupaten Blitar"

\section{Metode}

Penelitian ini merupakan penelitian kuantitatif menggunakan metode deskriptif untuk menjelaskan suatu fenomena yang ada di masyarakat. Sampel dalam penelitian ini adalah Semua orang tua di Desa Jatilengger RT 04/ RW 02 Kecamatan Ponggok Kabupaten Blitar sebanyak 30 responden. 
Hasil

Karakteristik Responden

a. Karakteristik responden berdasarkan umur di Desa Jatilengger RT04/RW02 Kecamatan Ponggok Kabupaten Blitar

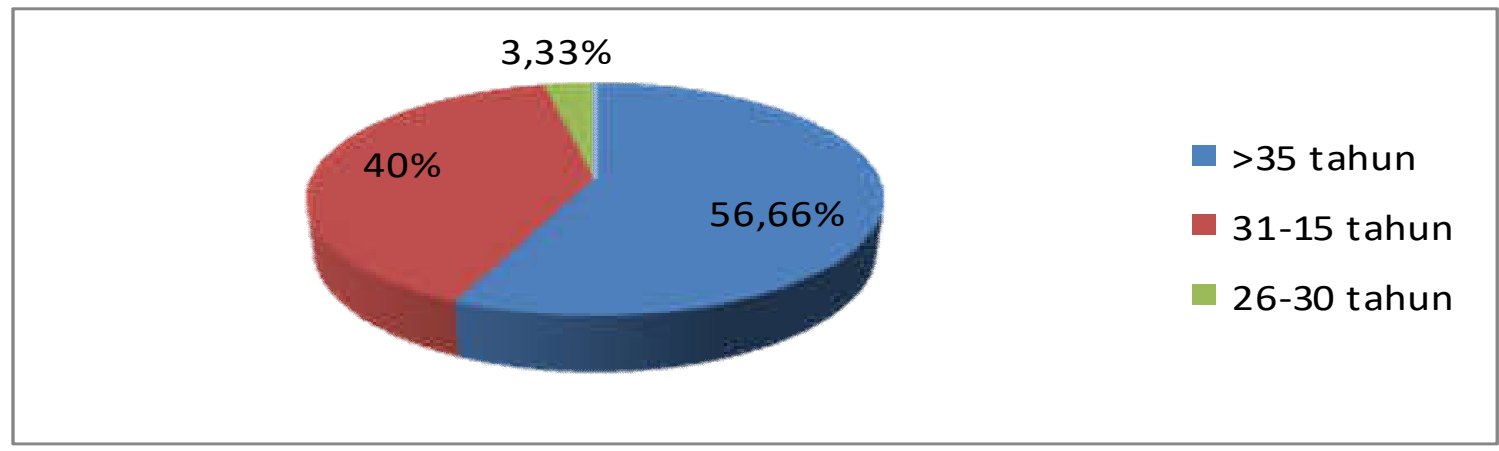

Berdasarkan gambar dari 30 responden di berusia diantara 31-35 tahun, dan 1 atas terlihat bahwa 17 responden $(56,66 \%)$ responden $(3,33 \%)$ berusia diantara $26-30$ berusia >35tahun, 12 responden $(40 \%)$ tahun.

b. KarakteristikResponden Berdasarkan Pendidikan

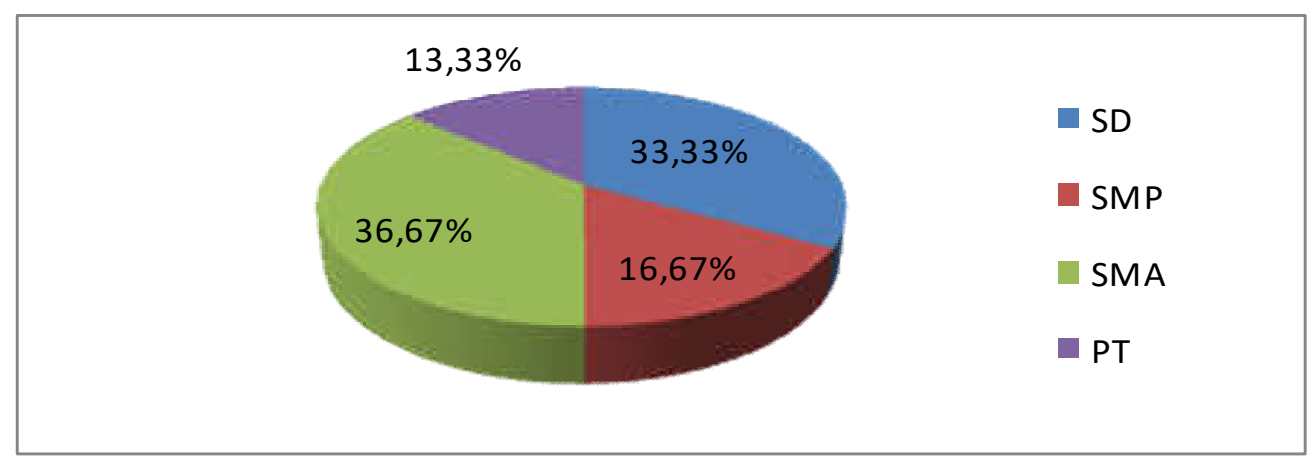

Berdasarkan diagram diatas sebanyak 10 responden $(36,67 \%)$ berpendidikan SMA, 4 responden $(33,33 \%)$ berpendidikan $\mathrm{SD}, 5$ responden $(13,33 \%)$ perguruan tinggi. responden $(16,67 \%)$ berpendidikan SMP, 11

c. Karakteristik Responden Berdasarkan Pekerjaan

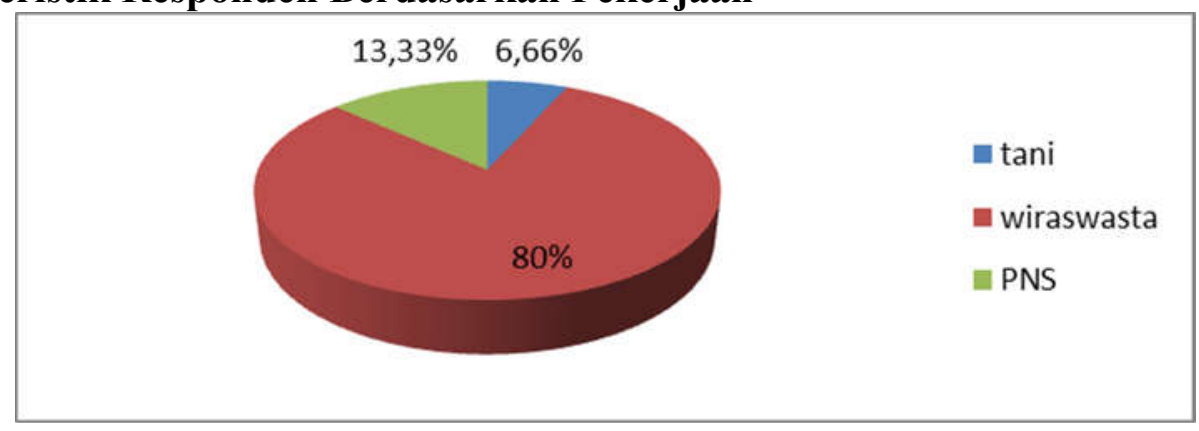

31 | Jurnal Kebidanan Dharma Husada Vol. 7, No. 1 April 2018 
Berdasarkan diagram 4 responden $(6,66 \%)$ bekerja sebagai wiraswasta, dan 4 responden bekerja sebagai tani, 24 responden $(80 \%) \quad(13,33 \%)$ bekerja sebagai PNS.

\section{d. Karakteristik Responden Berdasarkan Informasi yang Diperoleh}

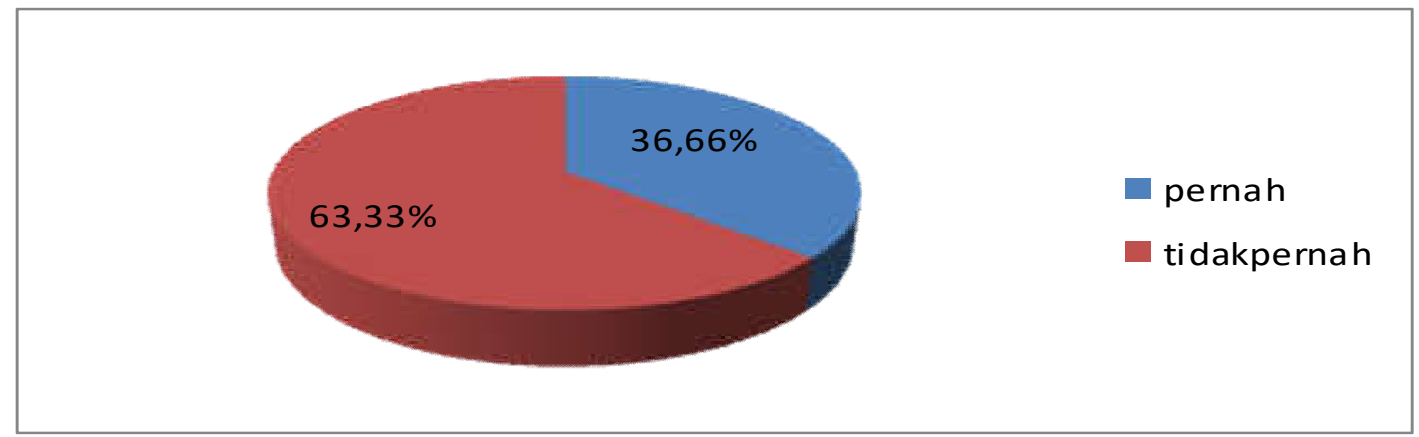

Berdasarkan gambar diketahui sebanyak 11 pernah memperoleh informasi tentang responden $(36,66 \%)$ pernah memperoleh pendidikan seks pada remaja. informasi tentang pendidikan seks pada remaja dan 19 responden $(63,33 \%)$ tidak

e. Karakteristik Responden Berdasarkan sumber informasi yang Diterima

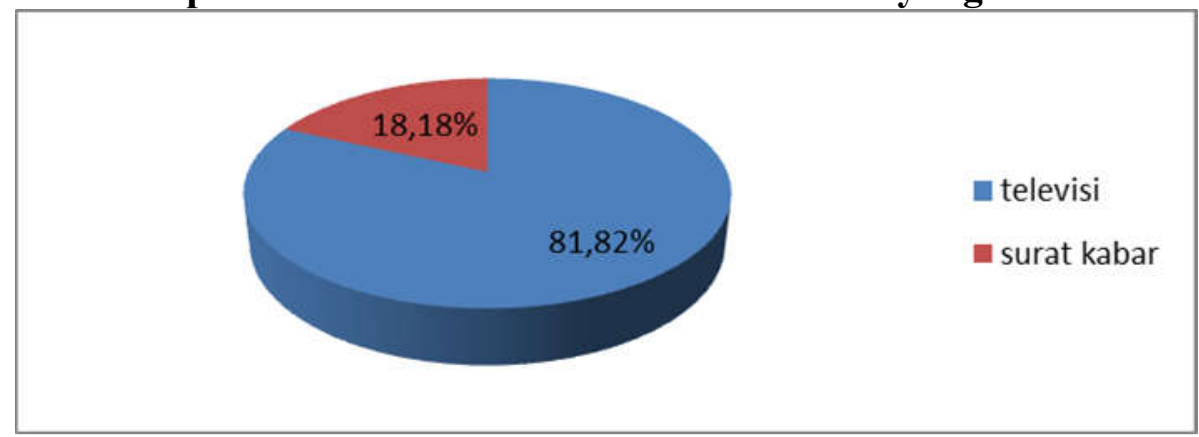

Dilihat dari gambar IV.7 dari 30 responden diketahui sebanyak 2 responden $(18,18 \%)$ diketahui sebanyak 9 responden $(81,82 \%)$ memperoleh informasi dari surat kabar. pernah memperoleh informasi tentang pendidikan seks pada remaja dari televisi dan

\section{f. Komponen Sikap Orang Tua Tentang Pendidikan Seks Pada Remaja Di Desa Jatilengger RT04/RW02 Kecamatan Ponggok Kabupaten Blitar.}

\begin{tabular}{|c|c|c|c|c|c|c|c|}
\hline \multirow{2}{*}{ No } & Kriteria & \multicolumn{6}{|c|}{ Komponen Sikap } \\
\hline & sikap & Kognitif & $\%$ & Afektif & $\%$ & Konatif & $\%$ \\
\hline 1 & Positif & 24 & $80 \%$ & 15 & $50 \%$ & 11 & $36,66 \%$ \\
\hline 2 & Negatif & 6 & $20 \%$ & 15 & $50 \%$ & 19 & $63,33 \%$ \\
\hline & & 30 & $100 \%$ & 46 & $100 \%$ & 46 & $100 \%$ \\
\hline
\end{tabular}


Dari tabel diatas menunjukan bahwa, komponen sikap kognitif dari 30 responden diketahui sebanyak 24 responden $80 \%$ menanggapi pendidikan seks pada remaja dengan perilaku positif dan 6 responden $20 \%$ menanggapi pendidikan seks pada remaja dengan perilaku negatif, komponen sikap afektif dari 30 responden diketahui sebanyak 15 responden $50 \%$ menghadapi pendidikan Diskusi

Dari hasil penelitian menunjukkan bahwa dari segi komponene sikap kognitif orang tua tentang pendidikan seks pada remaja di Desa Jatilengger Kecamatan Ponggok Kabupaten Blitar dengan sikap positif sebanyak 24 responden (80\%).

Dari segi komponen kognitif pembentukan sikap, sikap seseorang dipengaruhi olehhal yang berkaitan dengan pengetahuan, pandangan, keyakinan, yaitu hal-hal yang berhubungan dengan bagaimana orang mempersepsikan terhadap sikap.(Wawan, $2010: 32$ ).

Pengetahuan atau pandangan seseorang disini dipengaruhi oleh beberapa faktor diantaranya media masa atau sumber informasi dan pengalaman pribadi juga dapat mempengaruhi sikap. Dari hasil penelitian didapatkan 11 responden $36,66 \%$ orang tua pernah mendapat informasi tentang pendidikan seks pada remaja dan 19 responden $63,33 \%$ orang tua belum pernah mendapat informasi tentang pendidikan seks pada remaja. Hal itu sesuai dengan teori yang dikemukakan Azwar bahwa media masa mempunyai pengaruh yang sangat besar dalam pembentukan opini dan kepercayaan orang. Meskipun pengaruh media masa tidak sebesar pengaruh interaksi individual secara langsung namun dalam proses pembentukan dan perubahan sikap, peranan media masa tidakkecil artinya (Azwar, 2011: 34). Informasi yang diperoleh mempengaruhi pemikiran individu dalam menentukan sikap. seks pada remaja dengan sikap positif dan 15 responden $50 \%$ menghadapi pendidikan seks pada remaja dengan sikap negatif dan sikap konatif dari 30 responden diketahui sebanyak 11 responden $36,66 \%$ menanggapi pendidikan seks pada remaja dengan perilaku positif dan 19 responden 63,33\% menanggapi pendidikan seks pada remaja dengan perilaku negatif.

Informasi yang kurang pada individu dapat mempengaruhi sikap dari pada individu itu sendiri. Dari 11 responden 36,66\% yang sudah pernah memperoleh informasi mengenai pendidikan seks pada remaja 9 responden $81,82 \%$ memperoleh informasi dari televisi, 2 responden $18,18 \%$ memperoleh informasi dari surat kabar.

Sedikitnya sumber informasi akan memberikan pengaruh terhadap sikap seseorang, semakin banyak media masa yang disediakan dan informasi yang diperoleh maka semakin banyak pula seseorang itu dan mengerti, sehingga semakin banyak informasi akan mempengaruhi sikap seseorang, akan tetapi ketersediaan media masa tanpa didukung kehendak dan kemauan seseorang juga belum bisa menjamin baiknya sikap seseorang.

Orang tua yang memperoleh informasi mengenai pendidikan seks pada remaja akan cenderung bersikap positif. Hal ini karena para orang tua menjadi lebih memahami tentang hakikat dan tujuan pendidikan seks yang diberikan pada remaja tersebut. Maka dari itu perlu adanya sumber-sumber informasi yang memadai mengenai pendidikan seks pada remaja, baik melalui lembaga pendidikan, atau lembaga-lembaga terkait lainnya.

\section{a. Sikap Negatif}

Dari hasil penelitian menunjukkan bahwa sikap negatif orang tua tentang pendidikan seks pada remaja di Desa Jatilengger RT04/RW02 Kecamatan Ponggok 
Kabupaten Blitar dilihat dari komponen kognitif sebanyak 6 responden $(20 \%)$.

Dari komponen kognitif pembentukan sikap, sikap dipengaruhi oleh representasi apa yang dipercayai atau diketahui oleh individu pemilik sikap,berkaitan dengan pengetahuan, pandangan, keyakinan, yaitu hal-hal yang berhubungan dengan bagaimana orang mempersepsikan terhadap sikap. (Wawan, $2010: 32$ )

Dari hasil penelitian didapatkan 10 responden $(33,33 \%)$ berpendidikan SD, 5 responden $(16,67 \%)$ berpendidikan SMP, 11 responden (36,67\%) berpendidikan SMA, dan 4 responden $(13,33 \%)$ perguruan tinggi. Hal ini sesuai teori yang dikemukakan Sobur bahwa keteraturan dari berbagai informasi yang harus kita asimilasikan dalam kehidupan sehari-hari, dikatakan memiliki fungsi pengetahuan.Sikap tersebut adalah skema penting yang memungkinkan kita mengorganisasi dan mengolah berbagai informasi secara efisien tanpa harus memperhatikan detailnya (Sobur, 2011: 370). Tingkat pendidikan berpengaruh dalam mengolah dan mencerna informasi-informasi yang diperoleh sehingga sikap yang ditimbulkan bervariasi.

Dengan tingkat pendidikan yang rendah maka pengetahuan terhadap objek tertentu juga rendah. Hal ini dapat mempengaruhi pengambilan sikap seseorang terhadap suatu objek tersebut. Orang tua yang mempunyai pengetahuan yang kurang tentang pendidikan seks pada remaja akan cenderung bersikap negatif. Mereka mungkin menganggap pendidikan seks yang diberikan pada remaja suatu hal yang tidak perlu atau tabu untuk dibicarakan. Kemudian banyaknya orang tua yang berpendidikan rendah ini perlu diberikan informasi yang mudah dimengerti tentang pentingnya pendidikan seks pada remaja misalnya melalui perkumpulan RT/RW maupun sosialisasi dari dinas pendidikan ataupun dinas terkait lainnya agar para orang tua dapat merubah pandangan maupun sikapnya tentang pendidikan seks pada remaja tersebut.

\section{Berdasarkan Komponen Afektif Sikap}

a. Sikap Positif

Apabila dilihat dari komponen afektif pembentukan sikap, sikap positif orang tua tentang pendidikan seks pada remaja sebanyak 15 responden (50\%). Dari segi afektif sikap seseorang ini terbentuk dari perasaan individu terhadap objek sikap dan menyangkut masalah emosi. Aspek emosional inilah yang biasanya berakar paling dalam sebagai komponen sikap dan merupakan aspek yang paling bertahan terhadap pengaruh-pengaruh yang mungkin akan mengubah sikap seseorang. Komponen afektif menyangkut masalah emosional subjektif seseorang terhadap suatu objek sikap.Secara umum komponen ini disamakan dengan perasaan yang dimiliki terhadap sesuatu.(Wawan, $2010: 32$ )

Perasaan senang atau tidak senang pada sesuatu dapat dipengaruhi oleh interaksi sosial yang dialami oleh individu juga dapat mempengaruhi sikap individu. Interaksi sosial bisa berbentuk di dalam atau diluar rumah. Pada penelitian ini diperoleh hasil bahwa 18 responden $60 \%$ orang tua mempunyai kebiasaan sehari-hari di rumah, dan 12 responden $40 \%$ orang tua mempunyai kebiasaan sehari-hari diluar rumah. Hal ini sesuai dengan yang dikemukakan Azwar, bahwa sikap sosial terbentuk dari adanya interaksi sosial yang di alami oleh individu (Azwar, 2011: 30). Manusia merupakan makhluk sosial yang tidak dapat hidup sendiri, karena itu sosialisasi dan komunikasi dengan lingkungan sekitar perlu dijaga.

Apabila orang tua ada pada lingkungan yang kondusif, mereka akan memperoleh sifatsifat positif yang mengembangkan nilai-nilai insaninya. Karena lingkungan yang kodusif bisa menyebabkan interaksi yang kondusif. Interaksi yang kondusif ini yang dapat membentuk kepribadian seseorang yang tampak dari cara bicara, berfikir maupun cara pandangnya terhadap sesuatu, tentunya pandangannya yang positif.

Maka dari itu interaksi sosial yang positif yang dilakukan orang tua baik dari aktifitasnya yang dilakukan di dalam rumah 
ataupun di luar rumah perlu di pertahankan atau dijaga agar dapat membentuk sikap atau pandangan yang positif terhadap objek tertentu khususnya tentang pendidikan seks pada remaja ini.

b. Sikap Negatif

Dari segi komponen afektif pembentukan sikap,sikap orang tua tentang pendidikan seks pada remaja sebanyak 15 responden $(50 \%)$. Dari segi afektif sikap seseorang dipengaruhi oleh perasaan individu terhadap objek sikap dan menyangkut masalah emosi. Aspek emosional inilah yang biasanya berakar paling dalam sebagai komponen sikap dan merupakan aspek yang paling bertahan terhadap pengaruh-pengaruh yang mungkin akan mengubah sikap seseorang. Komponen afektif menyangkut masalah emosional subjektif seseorang terhadap suatu objek sikap.Komponen ini yang berhubungan dengan rasa senang atau tidak senang terhadap objek sikap. (Wawan, 2010 : 32).

Rasa senang atau tidak senang dapat dipengaruhi oleh pengalaman pribadi cenderung membentuk sikap negatif terhadap sesuatu. Pengalaman ini diaplikasikan ke sikap tanpa dimusyawarahkan, tanpa meminta pendapat orang lain. Dari hasil penelitian diketahui sebanyak 30 responden (100\%) memiliki status menikah. Jadi tidak terdapat responden yang berstatus janda/duda. Sikap negatif ini tumbuh karena mempunyai beragam pengalaman, baik itu pahit maupun manis dari orang terdekat orang tua yaitu suami atau istrinya. Hal ini sesuai yang dikemukakan oleh Azwar, bahwa individu cenderung untuk memiliki sikap yang konfornis, terhadap orang yang dianggapnya penting domotifasi oleh keinginan untuk berafiliasi atau beranggota dan keinginan itu untuk menghindari konflik dengan orang yang dianggap penting tersebut (Azwar, 2011: 32). Individu yang dianggap penting merupakan orang terdekat dan paling sering berinteraksi dengan respomden.

Orang yang terdekat dengan orang tua atau orang yang dianggap penting dapat mempengaruhi pengambilan sikap seseorang. Apabila orang yang terdekat tersebut tidak memberi dukungan atau bersikap negatif terhadap objek tertentu maka berpengaruh besar pada pengambilan sikap seseorang tersebut, karena pada umumnya individu cenderung untuk memiliki sikap yang searah dengan orang yang dianggap penting.

Oleh karena itu orang terdekat dari orang tua perlu memberikan dukungan atau memberikan pandangan yang positif terhadap pendidikan seks pada remaja ini, hal ini karena mereka memiliki peran yang besar dalam pembentukkan sikap orang tua tersebut. Dengan dukungan yang positif atau sikap yang positif tentang pendidikan seks pada remaja dari orang terdekat maka orang tua akan bersikap searah atau positif pula.

\section{Berdasarkan Komponen Konatif Sikap}

\section{a. Sikap Positif}

Dilihat dari komponen konatif pembentukan sikap positif orang tua tentang pendidikan seks pada remaja sebanyak 11 responden $(36,66 \%)$. Dari segi konatif menunjukkan bagaimana prilaku atau kecenderungan berprilaku yang ada didalam diri seseorang berkaitan dengan objek sikap yang dihadapinya. Komponen ini berhubungan dengan kecenderungan bertindak terhadap objek sikap. (Wawan, 2010 : 32).

Kecenderungan bertindak terhadap sesuatu objek ini dapat dipengaruhi oleh umur atau kedewasaan seseorang. Hasil penelitian menunjukkan dari 30 responden di atas terlihat bahwa 17 responden $(56,66 \%)$ berusia >35tahun, 12 responden $(40 \%)$ berusia diantara 31-35 tahun, dan 1 responden $(3,33 \%)$ berusia diantara 2630tahun.

Menurut (Soemarmi, 2006), semakin tua usia individu semakin meningkat pula 
kematangan berbagai fungsi fisiologi. Dengan bertambahnya umur maka pertumbuhan seseorang akan berlangsung terus meneruskepada tingkat kematangan tertentu pada fungsi-fungsi jansmani. Semakin cukup umur tingkat kematangan kekuatan seseorang akan lebih matang dalam berfikir dan bekerja.

Semakin dewasa seseorang maka semakin banyak pengalaman-pengalaman hidup yang telah di dapat yang kemudian tertanam nilainilai pada dirinya, dan kemudian dapat mempengaruhi seseorang dalam pengambilan sikap atau perilaku pada objek tertentu.

Dengan kedewasaan orang tua diharapkan semakin terbukanya wawasan dan pengetahuan terhadap objek tertentu. Dan orang tua juga diharapkan semakin mampu menilai atau memberikan pandangan yang positif tentang pendidikan seks pada remaja ini. Selanjutnya dengan pandangan yang positif tersebut kemudian dapat merubah sikap orang tua yang negatif menjadi bersikap positif tentang pendidikan seks pada remaja tersebut.

b. Sikap Negatif

Dilihat dari komponen konatif pembentukan sikap, sikap negatif orang tua tentang pendidikan seks pada remaja sebanyak 19 responden $(63,33 \%)$. Dari segi konatif sikap dipengaruhi oleh hal berhubungan dengan kecenderungan bertindak terhadap objek sikap. (Wawan, 2010 : 32).

\section{Simpulan}

Dari berbagai komponen sikap didapatkan bahwasanya sikap orang tua tentang pendidikan seks pada remaja adalah positif sebanyak 14 responden (46,66\%). Dari berbagai komponen sikap didapatkan bahwasanya sikap orang tua tentang pendidikan seks pada remaja adalah negatif 16 sebanyak responden $(53,33 \%)$.
Pribadi yang cenderung acuh atau sibuk dalam kehidupan sehari-hari secara tidak langsung mempengaruhi pembentukan sikapnya. Disini orang tua yang terfokus dengan urusan pekerjaannya sehingga mereka tidak mempunyai waktu untuk memperhatikan perubahan-perubahan yang dialami remaja. Dengan situasi seperti ini orang tua akan cenderung membentuk sikap negatif. Dari hasil penelitian menunjukkan dari 30 responden 2 responden $6,66 \%$ bekerja sebagai petani, 24 responden bekerja wiraswasata, 4 responden PNS.

Kesibukan orang tua inilah yang dapat membentuk sikap negatif, karena dengan kesibukannya orang tua cenderung bersikap acuh dan tidak memperhatikan perubahanperubahan yang terjadi di sekitarnya khususnya perubahan pada pergaulan para remaja pada saat ini.

Maka dari itu perlu meningkatkan sosialisasi tentang pendidikan terhadap orang tua melalui kelompok belajar, perkumpulan RT/RW, kelurahan. Agar para orang tua dapat lebih memahami tentang pendidikan seks remaja. Dan supaya para orang tua dapat merubah pandangan dan sikapnya tentang pendidikan seks pada remaja. Kemudian dengan perluasan informasi pada institusi terkait seperti Dikbud, Diknas, KUA dan instansi kesehatan untuk penyebarluasan pendidikan seks remaja pada orang tua.

Adanya anggapan tabu pada beberapa orang tua tentang pendidikan seks pada remaja perlu mendapatkan perhatian dari petugas kesehatan mengenai pemberian informasi mengenai kesehatan reproduksi dan pendidikan seks dengan pendekatan sesuai tahap perkembangan remaja. 
Daftar Pustaka

Azwar, Syaifudin. 2009. Sikap Manusia dan Teori Pengukurannya. Yogyakarta: Pustaka Pelajar.

Hidayat, A. Aziz Alimul. 2010. Metode Penelitian Kebidanan \& Teknik Analisis Data. Jakarta: Salemba Medika.

Maryam, Siti. 2012. Peran Bidan yang Kompeten Terhadap Suksesnya MDG's. Jakarta: Salemba Medika.

Notoadmodjo, Soekidjo. 2010. Metodologi Penelitian Kesehatan. Jakarta: Rineka Cipta.

Notoadmodjo, Soekidjo. 2011. Kesehatan Masyarakat Ilmu dan Seni. Jakarta: Rineka Cipta.

Nawita, Muslik. 2013. Bagaimana Menjelaskan Seks pada Anak.Bandung: Yrama Widya.
Nursalam. 2003. Konsep dan Penerapan Metodologi Penelitian Ilmu Keperawatan. Jakarta: Salemba Medika.

2011. Konsep dan Penerapan

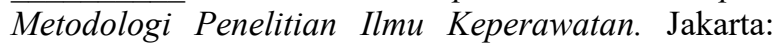
Salemba Medika.

Suherman, A. Sherly. 2013. Edukasi Seks untuk Remaja. Bandung: Yrama Widya.

Sunaryo. 2004. Psikoogi Untuk Keperawatan. Jakarta: EGC.

Ahmadi, Abu. 2008. Psikologi Sosial. Jakarta : PT. Rineka Cipta

Wawan, Dewi. 2010. Pengetahuan, Sikap dan Perilaku Manusia. Yogyakarta: Nuha Medika.

Admin. (2009). Pendidikan Seks pada Remaja. Available from : http://www.inimedanbung.com 